\title{
FAKTOR - FAKTOR YANG BERHUBUNGAN DENGAN PEMILIHAN TEMPAT PERSALINAN DI DESA SIAGA WILAYAH PUSKESMAS KALIANGKRIK KABUPATEN MAGELANG
}

\author{
Dian Puspitasari ${ }^{1}$ \\ Email: dian.ayaniyka@gmail.com \\ ${ }^{1}$ Fakultas Kesehatan Prodi Kebidanan (D-3) Universitas Jenderal Achmad Yani \\ Yogyakarta Jln. Brawijaya Ambarketawang Gamping Sleman
}

\begin{abstract}
Abstrak
Program Desa Siaga adalah bentuk pendekatan pelayanan kesehatan dan pemberdayaan masyarakat agar dapat hidup mandiri di bidang kesehatan, melalui Desa Siaga diharapkan dapat meningkatkan cakupan persalinan oleh tenaga kesehatan (nakes) di fasilitas kesehatan. Penelitian ini bertujuan untuk menganalisis faktor predisposisi, pendukung dan kebutuhan terhadap pemilihan tempat persalinan. Penelitian ini menggunakan pendekatan potong lintang dengan 130 responden. Data yang terkumpul dianalisis secara bivariabel dan multivariabel menggunakan uji chi-Square dan regresi logistik ganda. Hasil penelitian menunjukkan dari $130 \mathrm{ibu}$ yang bersalin dengan bidan desa, $70 \mathrm{ibu}$ memilih tempat persalinan di rumah. Variabel yang memiliki hubungan dengan pemilihan tempat persalinan adalah karakteristik predisposisi usia $(p=0,036)$, pendidikan $(p=0,001)$, paritas $(p=0,001)$, budaya $(p<0,001)$, sedangkan tingkat pengetahuan tidak berhubungan $(\mathrm{p}=0,796)$. Karakteristik pendukung penghasilan keluarga $(\mathrm{p}<0,001)$ memiliki hubungan, sedangkan jarak $(\mathrm{p}=0,329)$, manfaat askes $(\mathrm{p}=0,288)$ dan persepsi tentang Desa Siaga $(\mathrm{p}=0,234)$ tidak ada hubungan. Karakteristik kebutuhan pengambil keputusan $(\mathrm{p}<0,001)$ dan kunjungan ANC $(\mathrm{p}<0,001)$ terdapat hubungan, sedangkan riwayat komplikasi hamil tidak ada hubungan $(p=0,972)$. Hasil analisis multivariabel menunjukkan karakteristik predisposisi (pendidikan, paritas, dan budaya), pendukung (penghasilan keluarga) serta kebutuhan (pengambil keputusan dan jumlah kunjungan ANC) berhubungan secara simultan terhadap pemilihan tempat persalinan di Desa Siaga. Jumlah kunjungan ANC merupakan faktor yang paling dominan berhubungan dengan pemilihan tempat persalinan. Simpulan dalam penelitian ini adalah terdapat hubungan antara karakteristik predisposisi, pendukung dan kebutuhan terhadap pemilihan tempat persalinan dan ketiga faktor tersebut secara simultan berhubungan terhadap pemilihan tempat persalinan di Desa Siaga Wilayah Puskesmas Kaliangkrik Kabupaten Magelang. Puskesmas diharapkan memperhatikan hal tersebut sehingga dapat meningkatkan pemanfaatan PKD.
\end{abstract}

Kata kunci : Desa Siaga, pemilihan tempat persalinan, PKD

\section{Pendahuluan}

Desa Siaga adalah salah satu program yang memiliki tujuan untuk meningkatkan cakupan persalinan oleh tenaga kesehatan (nakes) di fasilitas kesehatan berupa Pos 
Kesehatan Desa (PKD). Hal ini dilakukan dengan memfasilitasi PKD serta upaya kesehatan berbasis masyarakat (UKBM) dan menempatkan bidan desa yang berkompeten di setiap desa serta melatih para kader di masyarakat sebagai wujud pemberdayaan masyarakat ${ }^{1-4}$

Teori Andersen behavioral models of health service utilization mengemukakan bahwa keputusan untuk menggunakan pelayanan kesehatan dipengaruhi oleh tiga komponen, yaitu (1) karakteristik predisposisi (predisposing factors) terdiri dari demografi, struktur sosial dan kepercayaan kesehatan, (2) karakteristik pendukung (enabling factors) terdiri dari sumber daya keluarga (penghasilan keluarga, kemampuan membeli jasa pelayanan, keikutsertaan dalam asuransi kesehatan), dan sumber daya masyarakat (jumlah sarana pelayanan kesehatan, jumlah tenaga kesehatan, lokasi sarana kesehatan), (3) karakteristik kebutuhan (need factors) merupakan komponen yang paling langsung berpengaruh terhadap pelayanan kesehatan. Berdasarkan analisis teori tersebut, maka dapat disimpulkan determinan keputusan ibu untuk menentukan tempat persalinan dipengaruhi oleh faktor karakteristik individu seperti usia, pendidikan, pendapatan keluarga, riwayat persalinan, dan paritas. Selain itu juga dipengaruhi oleh dukungan keluarga serta masyarakat berupa Desa Siaga dan keterjangkauan terhadap pelayanan kesehatan., 5-7

Metode

$\begin{array}{ccr}\text { Penelitian } & \text { ini } & \text { merupakan } \\ \text { penelitian } & \text { analitik } & \text { dengan }\end{array}$

pendekatan potong lintang untuk mengetahui hubungan antara karakteristik predisposisi, pendukung dan kebutuhan ibu dengan pemilihan tempat persalinan. Populasi terjangkau dalam penelitian ini adalah ibu bersalin di wilayah Puskesmas Kaliangkrik Kabupaten Magelang yang berada di 20 desa memiliki strata Desa Siaga Aktif Madya dengan besar sampel sesuai rumus yang ditetapkan didapatkan 130 responden. Teknik pengambilan sampel yang dilakukan secara propotional random sampling. Analisis data untuk menghubungkan karakteristik predisposisi, pendukung dan kebutuhan dengan pemilihan tempat persalinan dilakukan dengan uji Chi-Square, kemudian dilanjutkan dengan melakukan analisis multivariabel dengan uji regresi logistik ganda. Kemaknaan hasil uji ditentukan berdasarkan nilai $\mathrm{p}<0,05$.

\section{Hasil}

Tabel 1. Karakteristik Presdisposisi, Pendukung, Kebutuhan Responden.

\begin{tabular}{|c|c|c|}
\hline Variabel & Frek & $\%$ \\
\hline \multicolumn{3}{|l|}{ Tempat Persalinan } \\
\hline Faskes & 60 & 46,2 \\
\hline Non-Faskes & 70 & 53,8 \\
\hline \multicolumn{3}{|l|}{ Predisposisi: } \\
\hline \multicolumn{3}{|l|}{ Usia Ibu: $<20$ tahun } \\
\hline 20 th -35 th & 91 & 70 \\
\hline$>35$ tahun & 17 & 13,1 \\
\hline \multicolumn{3}{|l|}{ Pendidikan: } \\
\hline PT & 6 & 4,6 \\
\hline SLTA & 13 & 10 \\
\hline SLTP & 41 & 31,5 \\
\hline SD & 70 & 53,8 \\
\hline \multicolumn{3}{|l|}{ Paritas : } \\
\hline Primipara & 44 & 33,8 \\
\hline Multipara & 86 & 66,2 \\
\hline \multicolumn{3}{|l|}{ Tingkat pengetahuan : } \\
\hline Tinggi & 71 & 54,6 \\
\hline Rendah & 59 & 45,4 \\
\hline \multicolumn{3}{|l|}{ Budaya Persalinan: } \\
\hline Tidak dukung & 81 & 62,3 \\
\hline Mendukung & 49 & 37,7 \\
\hline
\end{tabular}




\begin{tabular}{|c|c|c|}
\hline Variabel & Frek & $\%$ \\
\hline \multicolumn{3}{|l|}{ Pendukung: } \\
\hline \multicolumn{3}{|l|}{ Jarak ke Faskes (PKD) } \\
\hline Dekat & 121 & 93,1 \\
\hline Jauh & 9 & 6,9 \\
\hline \multicolumn{3}{|l|}{ Penghasilan Keluarga } \\
\hline$\geq \mathrm{UMR}$ & 52 & 40 \\
\hline$<\mathrm{UMR}$ & 78 & 60 \\
\hline \multicolumn{3}{|l|}{ Manfaat Askes } \\
\hline Bermanfaat & 126 & 98,5 \\
\hline Tidak & 2 & 1,5 \\
\hline \multicolumn{3}{|l|}{ Persepsi Desa Siaga } \\
\hline Berpengaruh & 125 & 96,2 \\
\hline Tidak & 5 & 3,8 \\
\hline \multicolumn{3}{|l|}{ Kebutuhan: } \\
\hline \multicolumn{3}{|l|}{$\overline{\text { Pengambilan keputusan }}$} \\
\hline Ibu & 38 & 29,2 \\
\hline Suami & 40 & 30,8 \\
\hline keluarga & 52 & 40 \\
\hline \multicolumn{3}{|l|}{ Riwayat komplikasi } \\
\hline Ada & 24 & 18,5 \\
\hline Tidak Ada & 106 & 81,5 \\
\hline \multicolumn{3}{|l|}{ Kunjungan ANC } \\
\hline$\geq 4$ kali & 101 & 77,7 \\
\hline$<4$ kali & 29 & 22,3 \\
\hline
\end{tabular}

Sebagian besar subjek penelitian yang memilih tempat persalinan di rumah, memiliki karakteristik predisposisi usia 20-35 tahun, SD, multipara, tingkat pengetahuan tinggi dan responden tidak mendukung budaya persalinan di rumah. Karakteristik responden dilihat dari faktor pendukung paling besar memiliki akses dekat ke tenaga kesehatan $(<5 \mathrm{~km})$, penghasilan keluarga dibawah UMR, memanfaatkan askes untuk persalinan dan merasakan pengaruh

pelaksanaan Desa Siaga. Apabila dilihat dari karakteristik kebutuhan paling besar keluarga sebagai pengambil keputusan, tidak memiliki riwayat komplikasi, dan melakukan kunjungan $\mathrm{ANC} \geq 4$ kali.

Tabel 2. Hubungan Karakteristik Predisposisi Dengan Pemilihan Tempat Persalinan Pemilihan Tempat

Variabel Persalinan

\begin{tabular}{|c|c|c|c|c|c|}
\hline \multicolumn{4}{|c|}{ Persalinan } & \multirow{3}{*}{ P value } & \multirow{3}{*}{ OR (IK $95 \%$ ) } \\
\hline & & & nah & & \\
\hline n & $\%$ & $\mathbf{N}$ & $\%$ & & \\
\hline
\end{tabular}

\section{Karakteristik Predisposisi:}

Usia Ibu :

20 th -35 tahun

$47 \quad 51,6 \quad 44$

$<20$ tahun

$\begin{array}{lll}10 & 45,5 & 12\end{array}$

$>35$ tahun

$3 \quad 17,6 \quad 14$

$\begin{array}{ll}48,4 & 0,036^{*} \\ 54,5 & \\ 82,4 & \end{array}$

$0,78(0,31-1,99)$

$3,89(0,86-17,48)$

Pendidikan Ibu :

$\begin{array}{lrrrrrr}\text { Perguruan Tinggi } & 6 & 100 & 0 & 0 & 0,001^{*} & \\ \text { SLTA } & 9 & 69,2 & 4 & 30,8 & & 1,44(1,01-2,08) \\ \text { SLTP } & 23 & 56,1 & 18 & 43,9 & & 1,78(1,36-2,34) \\ \text { SD } & 22 & 31,4 & 48 & 68,6 & 3,18(2,25-4,50)\end{array}$

Paritas :

$$
\begin{aligned}
& \text { Primipara (1) } \\
& \text { Multipara (2-4) }
\end{aligned}
$$$$
\begin{array}{lll}
30 & 68,2 & 14
\end{array}
$$

$30 \quad 34,9 \quad 56$

$31,8 \quad 0,001 *$

$$
65,1 \quad 4,0(1,85-8,67)
$$

Tingkat pengetahuan :

$\begin{array}{llllll}\quad & 34 & 47,9 & 37 & 52,1 & 0,796 \\ \begin{array}{l}\text { Tinggi } \\ \text { Rendah }\end{array} & 26 & 44,1 & 33 & 55,9 & \\ \text { Persalinan di } & & & & & \\ & 50 & 61,7 & 31 & 38,3 & <0,001^{*} \\ \text { Tidak mendukung } & 10 & 20,4 & 39 & 79,6 & \end{array}$

$1,2(0,58-2,33)$

Budaya Persalinan di

Rumah:

Mendukung

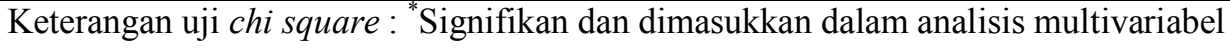


Terdapat beberapa variabel yang berhubungan dengan pemilihan tempat persalinan $(p<0,05)$ yaitu variabel usia, pendidikan, paritas dan budaya yang mendukung persalinan di rumah. Sedangkan variabel tingkat pengetahuan tidak memiliki hubungan dengan pemilihan tempat persalinan.

Tabel 3. Hubungan Karakteristik Pendukung Ibu Dengan Pemilihan Tempat Persalinan

\begin{tabular}{|c|c|c|c|c|c|c|}
\hline \multirow{3}{*}{ Variabel } & \multicolumn{4}{|c|}{$\begin{array}{c}\text { Pemilihan Tempat } \\
\text { Persalinan }\end{array}$} & \multirow{3}{*}{ P value } & \multirow{3}{*}{ OR $($ IK $95 \%)$} \\
\hline & \multicolumn{2}{|c|}{ PKD } & \multicolumn{2}{|c|}{ Rumah } & & \\
\hline & $\mathbf{N}$ & $\%$ & $\mathbf{n}$ & $\%$ & & \\
\hline \multicolumn{7}{|l|}{ Karakterisik Pendukung: } \\
\hline \multicolumn{7}{|l|}{ Jarak ke PKD } \\
\hline Dekat $(<5 \mathrm{~km})$ & 57 & 47,1 & 64 & 52,9 & 0,329 & \\
\hline $\operatorname{Jauh}(\geq 5 \mathrm{~km})$ & 3 & 33,3 & 6 & 66,7 & & $1,8(0,43-7,45)$ \\
\hline \multicolumn{7}{|l|}{ Penghasilan keluarga } \\
\hline$\geq$ Rp. $870.000,-(\geq \mathrm{UMR})$ & 36 & 69,2 & 16 & 30,8 & $<0,001^{*}$ & \\
\hline$<$ Rp. 870.000,- $(<\mathrm{UMR})$ & 24 & 30,8 & 54 & 69,2 & & $5,1(2,37-10,83)$ \\
\hline \multicolumn{7}{|l|}{ Manfaat askes } \\
\hline Bermanfaat & 60 & 46,9 & 68 & 53,1 & 0,288 & \\
\hline Tidak Bermanfaat & 0 & 0 & 2 & 100 & & $0,5(30,45-0,63)$ \\
\hline \multicolumn{7}{|l|}{$\begin{array}{l}\text { Persepsi tentang pelaksanaan } \\
\text { Desa Siaga }\end{array}$} \\
\hline Desa Siaga & & & & & & \\
\hline Berpengaruh & 59 & 47,2 & 66 & 52,8 & 0,234 & \\
\hline Tidak berpengaruh & 1 & 20,0 & 4 & 80,0 & & $3,5(80,39-32,9)$ \\
\hline
\end{tabular}

Keterangan uji chi square: "Signifikan dan dimasukkan dalam analisis multivariabel

Terdapat satu variabel pendukung yang berhubungan dengan pemilihan tempat persalinan $(\mathrm{p}<0,05)$ yaitu variabel penghasilan keluarga sedangkan variabel jarak ke fasilitas kesehatan, manfaat askes, persepsi tentang pelaksanaan Desa Siaga tidak menunjukkan hubungan dengan pemilihan tempat persalinan.

Tabel 4. Hubungan karakteristik Kebutuhan Ibu Dengan Pemilihan Tempat Persalinan

\begin{tabular}{|c|c|c|c|c|c|c|}
\hline \multirow{3}{*}{ Variabel } & \multicolumn{4}{|c|}{$\begin{array}{c}\text { Pemilihan Tempat } \\
\text { Persalinan }\end{array}$} & \multirow{3}{*}{ P value } & \multirow{3}{*}{ OR (IK $95 \%)$} \\
\hline & \multicolumn{2}{|c|}{ PKD } & \multicolumn{2}{|c|}{ Rumah } & & \\
\hline & $\mathbf{N}$ & $\%$ & n & $\%$ & & \\
\hline \multicolumn{7}{|c|}{ Karakteristik Kebutuhan: } \\
\hline \multicolumn{7}{|l|}{ Pengambilan keputusan } \\
\hline $\mathrm{Ibu}$ & 29 & 76,3 & 9 & 23,7 & $<0,001^{*}$ & \\
\hline Suami & 18 & 45,0 & 22 & 55,0 & & $3,94(1,49-10,42)$ \\
\hline Keluarga & 13 & 25,0 & 39 & 75,0 & & $9,68(3,64-25,66)$ \\
\hline \multicolumn{7}{|c|}{$\begin{array}{l}\text { Riwayat komplikasi hamil dan } \\
\text { bersalin }\end{array}$} \\
\hline Ada & 11 & 45,8 & 13 & 54,2 & 0,972 & \\
\hline Tidak Ada & 49 & 46,2 & 57 & 53,8 & & $0,98(0,40-2,395)$ \\
\hline \multicolumn{7}{|l|}{ Kunjungan ANC } \\
\hline$\geq 4$ kali & 60 & 59,4 & 41 & 40,6 & $<0,001^{*}$ & \\
\hline$<4$ kali & 0 & 0 & 29 & 100 & & $0,4(10,32-0,51)$ \\
\hline
\end{tabular}

Keterangan uji chi square : "Signifikan dan dimasukkan dalam analisis multivariabel 
Terdapat dua variabel kebutuhan yang berhubungan dengan pemilihan tempat persalinan $(p<0,05)$ yaitu variabel pengambilan keputusan dalam keluarga dan variabel jumlah kunjungan ANC sedangkan variabel riwayat komplikasi kehamilan dan bersalin sebelumnya tidak menunjukkan hubungan dengan pemilihan tempat persalinan.

Tabel 4.6 Analisis Regresi Logistik ganda

\begin{tabular}{|c|c|c|c|c|}
\hline Variabel & B & SE (B) & Nilai p & OR (IK $95 \%$ ) \\
\hline \multicolumn{5}{|l|}{ Karakteristik Predisposisi } \\
\hline Pendidikan Ibu* & 2,094 & 0,700 & 0,003 & $8,12(2,06-32,03)$ \\
\hline Paritas* & 1,740 & 0,827 & 0,035 & $5,70(1,13-28,83)$ \\
\hline Budaya* & 2,503 & 0,940 & 0,008 & $12.22(1,94-77,12)$ \\
\hline \multicolumn{5}{|l|}{ Karakteristik Pendukung } \\
\hline Penghasilan Keluarga* & 1,327 & 0,775 & 0,087 & $3,77(0,83-17,22)$ \\
\hline \multicolumn{5}{|l|}{ Karakteristik Kebutuhan } \\
\hline Pengambilan keputusan* & 1,148 & 0,507 & 0,024 & $3,15(1,17-8,52)$ \\
\hline Kunjungan ANC* & 4,503 & 1,011 & 0,000 & $90,30(12,45-654,91)$ \\
\hline Konstanta & $-23,756$ & 5,138 & & \\
\hline
\end{tabular}

Hasil akhir analisis multivariabel didapatkan variabel yang mempunyai hubungan signifikan dengan pemilihan tempat persalinan adalah dari karakteristik predisposisi (pendidikan ibu, paritas, budaya), karakteristik pendukung (penghasilan keluarga) dan karakteristik kebutuhan (pengambilan keputusan dan kunjungan ANC) sedangkan yang paling dominan berhubungan dengan pemilihan tempat persalinan adalah variabel kunjungan ANC dengan nilai OR 90,30.

Dari hasil analisis multivariabel di atas didapatkan probabilitas ibu yang memilih persalinan di rumah sebesar $99,9 \%$ memiliki karakteristik pendidikan SD, multipara, mendukung budaya persalinan di rumah, dengan penghasilan keluarga di bawah UMR, pengambil keputusan adalah keluarga, dan kunjungan ANC kurang dari empat kali.

\section{Pembahasan}

Dalam penelitian ini dari 130 responden yang bersalin dengan bidan desa didapatkan paling besar memilih tempat persalinan di rumah yaitu 70 responden $(53,8 \%)$ dibanding memilih tempat persalinan di PKD 60 responden $(46,2 \%){ }^{8}$

1. Hubungan Karakteristik Predisposisi Ibu Dengan Pemilihan Tempat Persalinan

1) Usia ibu dengan pemilihan tempat persalinan

Hasil uji statistik menunjukkan nilai $(p<0,05)$, sehingga terdapat hubungan yang bermakna antara usia ibu dengan pemilihan tempat persalinan. Hasil penelitian ini sesuai dengan penelitian di Kenya Bagian Barat yang menunjukkan bahwa usia ibu lebih dari 30 tahun berhubungan signifikan dengan pemilihan persalinan di rumah. Akan tetapi hasil penelitian ini tidak sesuai dengan penelitian yang dilakukan di Kabupaten Rembang Provinsi Jawa Tengah yang menunjukkan bahwa kelompok usia sangat 
muda dan kelompok usia tua merupakan kelompok usia yang memanfaatkan pelayanan kesehatan karena penelitian di Rembang dihubungkan dengan morbiditas. 9,10

2) Pendidikan ibu dengan pemilihan tempat persalinan

Hasil uji statistik diperoleh nilai $(\mathrm{p}<0,05)$ maka disimpulkan terdapat hubungan signifikan antara pendidikan ibu dengan pemilihan tempat persalinan. Hasil penelitian ini sesuai dengan teori yang menyatakan pemanfaatan seseorang terhadap sarana pelayanan kesehatan dipengaruhi oleh tingkat pendidikan dan sosial budaya. Bila tingkat pendidikan dan sosial budaya baik, maka secara relatif pemanfaatan pelayanan kesehatan akan tinggi. Hal ini juga diperkuat oleh pendapat Lukito yang menyatakan pemanfaatan masyarakat terhadap berbagai fasilitas pelayanan kesehatan sangat dipengaruhi oleh tingkat pendidikan karena pendidikan berada pada faktor predisposisi, pendidikan dapat mempermudah atau sebagai predisposisi timbulnya perilaku dalam diri individu maupun masyarakat. Semakin tinggi tingkat pendidikan, maka akan semakin mudah seseorang untuk menerima dan memahami informasi sehingga akan lebih mudah merubah perilaku melalui sebuah perubahan. Hal ini juga untuk merubah perilaku dalam memanfaatkan kesehatan. ${ }^{11,12}$
3) Paritas ibu dengan pemilihan tempat persalinan

Hasil uji statistik diperoleh nilai $(p<0,05)$ yang berarti terdapat hubungan signifikan antara paritas dengan pemilihan tempat persalinan. Hal ini sejalan dengan hasil penelitian di Nepal multiparitas secara statistik berhubungan dengan meningkatnya risiko persalinan di rumah. Penelitian di Maharashtra State India juga melaporkan bahwa sebagian besar persalinan terjadi di rumah sebanyak 37\%, sementara di fasilitas swasta sebanyak $32 \%$ dan fasilitas publik sebanyak $31 \%$. Wanita dengan paritas yang lebih tinggi dan wanita yang tinggal di daerah pedesaan memiliki kecenderungan yang lebih tinggi untuk melahirkan di rumah. Di Indonesia juga menunjukkan bahwa semakin meningkat paritas akan semakin meningkat peluang persalinan rumah yang ditolong oleh non tenaga kesehatan. Wanita yang tinggal di daerah pedesaan dengan paritas yang lebih tinggi memiliki kecenderungan yang lebih besar untuk melahirkan di rumah. $^{1314,15}$

4) Pengetahuan ibu dengan pemilihan tempat persalinan Hasil uji statistik menunjukkan tidak adanya hubungan yang signifikan antara tingkat pengetahuan dengan pemilihan tempat persalinan $(p>0,05)$. Penelitian ini tidak sesuai dengan penelitian di Tanzania Selatan yang melaporkan bahwa salah satu faktor yang memengaruhi ibu 
untuk bersalin di rumah dengan ditolong oleh non tenaga kesehatan adalah rendahnya pengetahuan ibu tentang faktor risiko kehamilan dan persalinan. ${ }^{16}$ Penelitian ini juga tidak sesuai dengan hasil penelitian yang dilakukan di Puskesmas Playen I Kabupaten Gunung Kidul Yogyakarta menunjukkan bahwa terdapat hubungan yang signifikan antara pengetahuan ibu tentang kehamilan, persalinan dan nifas dengan pemilihan tempat persalinan pada keluarga miskin, karena pada penelitian ini lebih difokuskan pada keluarga miskin.

Tidak sesuainya faktor pengetahuan ini dimungkinkan karena di daerah penelitian dilaksanakan program kelas ibu pada ibu hamil, sehingga ibu hamil mengerti tentang faktor risiko dan penanganan ibu hamil dan persalinan, akan tetapi di wilayah penelitian ini faktor pengetahuan bukan merupakan faktor utama dalam menentukan pemilihan tempat persalinan. Dilihat dari hasil penelitian ini ibu-ibu dengan pengetahuan tinggi memiliki karakteristik 51\% mendukung budaya persalinan di rumah, paling tinggi multiparitas dan pengambilan keputusan adalah suami atau keluarga.

5) Budaya/tradisi persalinan di rumah dengan pemilihan tempat persalinan

Hasil uji statistik didapatkan nilai $(p<0,05)$ yang berarti terdapat hubungan yang signifikan antara budaya persalinan dirumah dengan pemilihan tempat persalinan. Hal tersebut di atas sesuai dengan alasan yang didapatkan dari data kuesioner terdapat $12,42 \%$ ibu mengatakan bahwa persalinan di rumah merupakan tradisi atau kebiasaan yang turun menurun dan $9,8 \%$ ibu menyatakan bahwa semua persalinan sebelumnya di rumah, sehingga alasan tersebut yang merupakan budaya mengapa ibu memilih persalinan di rumah. Selain dari alasan tersebut di wilayah penelitian terdapat 30 dukun bayi terlatih yang masih menjadi kepercayaan masyarakat untuk menolong atau mendampingi serta merawat ibu dalam proses persalinan dan nifas. Meskipun ditolong bidan, masyarakat merasakan aman dan nyaman jika persalinan di rumah karena akan lebih leluasa ditunggui oleh dukun bayi dan keluarga.

2. Hubungan Faktor Karakteristik Pendukung Ibu Dengan Pemilihan Tempat Persalinan

1) Jarak ke fasilitas kesehatan (PKD) dengan pemilihan tempat persalinan

Hasil uji statistik didapatkan nilai $(p<0,05)$ yang berarti tidak ada hubungan yang signifikan antara jarak ke PKD dengan pemilihan tempat persalinan karena masalah akses ke pelayanan kesehatan bukan menjadi masalah lagi pada Desa Siaga. Dari hasil analisis didapatkan rata-rata jarak responden ke PKD adalah 1,76 $\mathrm{km}$. Menurut data SDKI jarak tersebut termasuk jarak yang dekat tetapi untuk wilayah Puskesmas Kaliangkrik Kabupaten Magelang jarak tersebut tidak dapat diasumsikan 
dekat karena keadaan geografis wilayah yang sebagian besar berbukit-bukit dengan tanjakan yang cukup terjal dan jalan yang belum diaspal. Hasil penelitian ini sesuai dengan penelitian yang dilakukan di Puskesmas Kalibunder Sukabumi yang menyatakan tidak ada hubungan antara waktu tempuh dengan pemilihan penolong persalinan karena telah di tempatkannya bidan desa dan perawat kesehatan sebagai pembina di setiap desa. Hasil dalam penelitian ini tidak sesuai dengan penelitian di Kenya menyebutkan bahwa jarak ke fasilitas kesehatan lebih dari satu jam perjalanan merupakan faktor yang berhubungan signifikan dengan pemilihan persalinan di rumah. 7,9,17

2) Penghasilan keluarga dengan pemilihan tempat persalinan

Hasil uji statistik didapatkan nilai $(p<0,05)$ yang berarti terdapat hubungan yang signifikan antara penghasilan keluarga dengan pemilihan tempat persalinan. Menurut teori Andersen biaya merupakan faktor pendukung dalam pemanfaatan fasilitas kesehatan dan biaya ini berhubungan dengan penghasilan. Berdasarkan hasil analisis ditemukan bahwa status ekonomi atau penghasilan memiliki hubungan dengan pemilihan tempat persalinan. Hal ini didukung oleh penelitian Thind dan Banerjee yang melaporkan bahwa ibu dengan status ekonomi rendah mempunyai peluang dua kali lebih besar untuk bersalin di rumah ditolong oleh dukun dibandingkan ibu dengan status ekonomi yang tinggi. Begitu pula dengan penelitian Kokulu dan Oncel di pedesaan Turki yang menyatakan bahwa keputusan wanita untuk bersalin di rumah berhubungan dengan kesulitan ekonomi. Salah satu alasan yang didapat dari data kuesioner yaitu dikarenakan dengan persalinan di rumah biaya persalinannya lebih murah. $^{14,18}$

3) Manfaat askes dengan pemilihan tempat persalinan

Hasil uji statistik didapatkan nilai $(p>0,05)$ yang berarti tidak terdapat hubungan yang signifikan antara kepemilikan asuransi dengan pemilihan tempat persalinan. Hasil dari penelitian menyatakan bahwa hampir semua responden memiliki dan memanfaatkan asuransi kesehatan yang berupa askeskin dan Jampersal. Hal ini sesuai dengan program pemerintah mengenai berlakunya askeskin dan Jampersal sebagai asuransi persalinan. Didalam petunjuk teknis (juknis) pelaksanaan Jampersal menyebutkan bahwa Jampersal adalah pembiayaan pelayanan persalinan yang meliputi pemeriksaan kehamilan, pertolongan persalinan, pelayanan nifas termasuk pelayanan $\mathrm{KB}$ pasca persalinan dan pelayanan bayi baru lahir yang dilakukan oleh tenaga kesehatan di fasilitas kesehatan. ${ }^{19}$

Sesuai juknis Jampersal, seharusnya persalinan dengan Jampersal harus dilakukan oleh tenaga kesehatan di fasilitas kesehatan, pada kenyataannya 
pelayanan persalinan di rumah dengan bidan desa tetap berlaku Jampersal sehingga ibu lebih memilih persalinan di rumah dengan alasan bisa bebas ditemani keluarga dan tidak repot, mudah aman, nyaman, tetap dapat melakukan pekerjaan sehari hari dan karena budaya yang disebabkan tradisi turun menurun serta riwayat persalinan sebelumnya di rumah.

4) Persepsi tentang pelaksanaan Desa Siaga dengan pemilihan tempat persalinan

Hasil uji statistik diperoleh nilai $(p>0,05)$ yang berarti tidak terdapat hubungan signifikan antara persepsi tentang pelaksanaan Desa Siaga dengan pemilihan tempat persalinan. Dalam pelaksanaan Desa Siaga yang berhubungan dengan pemilihan tempat persalinan adalah dengan tersedianya PKD sebagai fasilitas tempat persalinan yang sesuai dengan standar asuhan pertolongan persalinan, tersedianya bidan desa serta adanya dukungan dari masyarakat. Jika dilihat dari persepsi ibu terhadap pelaksanaan Desa Siaga hampir seluruh responden merasakan pengaruh yang baik terhadap kesehatan karena PKD memiliki sarana prasarana yang lengkap, bidan juga memberikan asuhan komunitas dan persalinan dengan baik, serta masyarakat berperan aktif. Namun apabila hasil pengaruh tersebut dihubungkan dengan pemilihan tempat persalinan tidak memberikan hubungan yang signifikan karena dimungkinkan beberapa faktor lain yang mendukung ibu untuk melakukan persalinan di rumah lebih kuat.

3. Hubungan Faktor Karakteristik Kebutuhan Ibu dengan Pemilihan Tempat Persalinan

1) Pengambil keputusan dalam keluarga dengan pemilihan tempat persalinan

Hasil uji statistik didapatkan nilai $(p<0,05)$ yang berarti terdapat hubungan yang signifikan antara pengambil keputusan dengan pemilihan tempat persalinan. Pengambilan keputusan dalam keluarga menunjukkan hubungan yang bermakna dengan pemilihan tempat persalinan. Peran suami dan keluarga sebagai pengambil keputusan utama merupakan faktor penentu pemilihan rumah sebagai tempat persalinan. Hal ini sesuai dengan penelitian di pedesaan Tanzania yang menunjukkan bahwa pola kekuasaan pengambil keputusan dalam keluarga merupakan faktor utama yang menentukan tempat persalinan. Dalam penelitian ini menyatakan bahwa pengambil keputusan suami atau keluarga berpeluang lebih besar untuk memilih persalinan di rumah dibandingkan dengan ibu sebagai pegambil keputusan utama. Hal ini berhubungan erat dengan adanya budaya patriaki dalam masyarakat yang menempatkan laki-laki pada posisi yang lebih tinggi dari perempuan, sehingga wanita kurang memiliki otonomi dalam setiap pengambilan keputusan. ${ }^{20}$
2) Riwayat
komplikasi kehamilan dan persalinan 
dengan pemilihan tempat persalinan

Hasil uji statistik didapatkan nilai $(p>0,05)$ yang berarti tidak terdapat hubungan yang signifikan antara riwayat komplikasi dalam kehamilan dan persalinan dengan pemilihan tempat persalinan. Hasil penelitian ini tidak sesuai dengan teori Andersen, kondisi kehamilan merupakan faktor kebutuhan, kondisi kehamilan merupakan dasar dari stimulus untuk menggunakan pelayanan kesehatan. Hasil penelitian ini juga tidak sesuai dengan penelitian yang dilakukan di Kabupaten Banggai Kepulauan yang menyatakan riwayat komplikasi persalinan merupakan faktor yang berhubungan dengan persalinan di rumah. Ibu yang mempunyai riwayat komplikasi persalinan mempunyai peluang $24 \%$ lebih besar untuk menggunakan tenaga kesehatan pada persalinan di rumah dibandingkan dengan non tenaga kesehatan. $^{21}$

3) Jumlah kunjungan ANC dengan pemilihan tempat persalinan

Hasil uji statistik didapatkan nilai $(p<0,05)$ yang berarti terdapat hubungan yang signifikan antara jumlah kunjungan ANC dengan pemilihan tempat persalinan dan dari hasil analisis ini didapatkan OR 90,30 yang berarti memiliki peluang 90,3 kali memilih persalinan di rumah pada ibu dengan jumlah kunjungan ANC kurang dari 4 kali.
Penelitian ini sesuai dengan hasil penelitian yang telah ada yang menyebutkan jumlah kunjungan ANC merupakan faktor penentu yang berhubungan secara statistik pada persalinan rumah dengan tenaga non kesehatan. Ibu dengan kunjungan ANC $<4$ (empat) kali lebih cenderung untuk bersalin di rumah ditolong non tenaga kesehatan. Hal yang penting dan perlu ditekankan pada variabel jumlah kunjungan, bukan saja peningkatan frekuensi kunjungan ANC melainkan disertai dengan peningkatan pemberian informasi pesan atau nasehat kepada ibu dan keluarga. ${ }^{14}$

4. Hubungan Faktor Karakteristik Predisposisi, Pendukung dan Kebutuhan Ibu dengan Pemilihan Tempat Persalinan

Hasil analisis multivariabel pada penelitian ini menunjukkan bahwa pendidikan ibu, paritas, budaya terhadap persalinan di rumah, penghasilan keluarga, pengambil keputusan dan jumlah kunjungan ANC pada karakteristik predisposisi, pendukung dan kebutuhan berhubungan signifikan dengan pemilihan tempat persalinan. Pada persamaan analisis multivariabel regresi logistik diperoleh hasil peluang 99,97\%, yang dapat diasumsikan bahwa jika seorang ibu yang dengan pendidikan SD, multipara, memiliki budaya yang mendukung persalinan di rumah, penghasilan kelarga di bawah UMR, pengambil keputusan adalah keluarga dan dengan jumlah kunjungan ANC kurang 
dari 4 kali memiliki peluang untuk memilih tempat persalinan di rumah $99,97 \%$.

Hasil analisis ini sesuai dengan pendapat Andersen bahwa tinggi rendahnya pemanfaatan pelayanan kesehatan didasari oleh baik buruknya perilaku individu, keluarga dan masyarakat dalam memanfaatkan pelayanan kesehatan yang tersedia. ${ }^{22}$ Hasil penelitian ini sesuai dengan penelitian Sumiaty yang dilakukan di Kabupaten Banggai Kepulauan yang menyatakan faktor predisposisi, pendukung dan kebutuhan memiliki hubungan yang bermakna dengan penolong persalinan dirumah. Alasan ibu melahirkan di rumah dengan ditolong non-nakes yaitu karena kebiasaan. ${ }^{21}$ Hasil penelitian ini juga sesuai dengan penelitian yang di lakukan di Puskesmas Kalibunder Kabupaten Sukabumi tentang determinan pemilihan penolong persalinan dengan hasil bahwa faktor predisposisi, pendukung dan kebutuhan berpengaruh terhadap pemilihan penolong persalinan. $^{17}$

\section{Simpulan}

Berdasarkan hasil penelitian di atas dapat disimpulkan terdapat hubungan karakteristik predisposisi (usia ibu, pendidikan ibu, paritas dan budaya persalinan di rumah), karakteristik pendukung (penghasilan keluarga), Karakteristik kebutuhan (pengambil keputusan dalam keluarga dan jumlah kunjungan ANC) dengan pemilihan tempat persalinan dan ke tiga karakteristik secara simultan berhubungan dengan pemilihan tempat persalinan.

\section{Saran}

Bagi bidan di desa diharapkan dapat meningkatkan kualitas pelayanan ANC melalui Program Perencanaan Persalinan dan Pencegahan Komplikasi (P4K), serta meningkatkan kunjungan rumah yang bertujuan untuk memberikan pendidikan kesehatan tidak hanya pada ibu melainkan kepada suami dan keluarga lain sebagai pengambil keputusan dalam keluarga. Bagi Puskesmas Kaliangkrik diharapkan dapat meningkatkan kerjasama lintas sektor yang bertujuan memberdayakan masyarakat untuk memanfaatkan PKD serta melaksanakan program kelas ibu yang sasarannya tidak hanya ibu hamil saja melainkan juga tokoh masyarakat, tokoh agama, suami dan keluarga ibu hamil, serta meningkatkan pembinaan dukun bayi untuk mendukung pemanfaatan fasilitas kesehatan. Bagi Dinas Kesehatan Kabupaten Magelang diharapkan dapat meningkatkan kunjungan atau pengawasan pelaksanaan PWS-KIA, Desa Siaga, dan pelaksanaan kebijakan Jampersal sesuai juknis yang ada.

\section{Daftar Pustaka}

1. Departemen Kesehatan RI. Pedoman Pengembangan Desa Siaga. Jakarta: Depkes; 2006

2. Departemen Kesehatan. Bahan Acuan Desa Siap Antar Jaga (Siaga). Binkesmas, Jakarta: Depkes; 2006.

3. Departemen Kesehatan. Kebijakan dan Langkah-Langkah 
Pengembangan Desa Siaga. Jakarta: Binkesmas; 2006.

4. Dinas Kesehatan Kabupaten Magelang. Laporan Tahunan Kegiatan Program Kesehatan Ibu Kabupaten Magelang. Magelang: Dinkes Magelang; 2011.

5. Andersen RM. Revisiting the behavioral model and access to medical care: does it matter? Journal of Health and Social Behavior. 1995;36 (March):1-10.

6. Dinas Kesehatan Kabupaten Magelang. Hasil Survey dan Pelaporan Desa Siaga kabupaten Magelang Tahun 2011. Magelang: Dinkes Magelang; 2012.

7. Notoatmojo S. Pendidikan dan perilaku kesehatan. 7 E, editor. Jakarta: Rineka Cipta; 2010.

8. Departemen Kesehatan. Survey Demografi Kesehatan Indonesia. Jakarta: Depkes; 2007.

9. Eijk AMv, Bles HM, Odhiambo F, Ayisi JG, Blokland IE, Rosen $\mathrm{DH}$, et al. Use of antenatal services and delivery care among women in rural western Kenya: a community based survey. Reproductive Health. 2006;3:2:1742-55.

10. Mas'udah CTP. Hubungan karakteristik ibu keluarga miskin dengan pemilihan tempat pemeriksaan kehamilan di Kecamatan Sulang Kabupaten Rembang Tahun 2006. Jurnal Promosi Kesehatan Indonesia 2007;Vol.2/No.I/Januari 2007.

11. Azrul A. Strategi Percepatan Penurunan Kematian Ibu Melalui Peningkatan Kualitas Pelayanan, Advocasi Workshop Strategi dan Kegiatan yang Berhasil dalam
Program Safe Motherhood. Jakarta: Depkes RI; 2006.

12. Lukito. Pemanfaatan fasilitas kesehatan oleh masyarakat pedesaan. Yogyakarta. (Tesis). Yogyakarta: UGM; 2003.

13. Thind A, Mohani A, Banerjee K, Hagigi F. Where to deliver? Analysis of choice of delivery location from a national survey in India. BMC Public Health. 2008;8:29.

14. Thind A, Banerjee K. Home Deliveries In Indonesia : Who Provides Assistance. Journal of Community Health. 2004;29(4).

15. Wagle RR, Sabroe S, Nielsen BB. Socioeconomic and physical distance to the maternity hospital as predictors for place of delivery: an observation study from Nepal. BMC Pregnancy and Childbirth. 2004;4(8).

16. Mpembeni RN, Killewo JZ, Leshabari MT, Massawe SN, Jahn A, Mushi D, et al. Use pattern of maternal health services and determinants of skilled care during delivery in Southern Tanzania: implications for achievement of MDG-5 targets. BMC Pregnancy and Childbirth. 2007;7(29):1-7.

17. Sumintardi C. Determinan pemilihan penolong persalinan di Wilayah Kerja Puskesmas Kalibunder Kabupaten Sukabumi. (Tesis). Jakarta: Universitas Indonesia; 2012.

18. Kukulu K, S. O. Factors influencing women's decision to have a home birth in rural Turkey. PubMed Medical and Health Sciences. 2009;25(1):328. 
19. Kementerian Kesehatan Republik Indonesia. Peraturan Menteri Kesehatan Republik Indonesia Nomor 2562/MENKES/PER/XII/2011

Tentang Petunjuk Teknis Jaminan Persalinan. Jakarta; 2011.

20. Mrisho M, Schellenberg JA, Mushi AK, Obrist B, Mshinda H, Tanner M, et al. Factors affecting home delivery in rural Tanzania. Tropical Medicine and International Health. 2007;12 No 7:862-72.
21. Sumiaty. Determinan penolong persalinan di rumah di Kabupaten banggai Kepulauan. (Tesis). Yogyakarta: Universitas Gajah Mada Yogyakarta; 2010.

22. Notoatmojo S. Promosi kesehatan \& ilmu perilaku. Jakarta: Penerbit Rineka Cipta; 2007. 